\title{
Long-term partitioning of space between two territorial species of ants (Hymenoptera: Formicidae) and their effect on subordinate species
}

\author{
WoJciech CZECHOWSKI ${ }^{1}$, BÁlint MARKÓ ${ }^{2 *}$, AleXANDER RADCHENKO ${ }^{1}$ and Piotr ŚLIPIŃSKI ${ }^{1}$ \\ ${ }^{1}$ Museum and Institute of Zoology, Polish Academy of Sciences, Wilcza 64, 00-679 Warsaw, Poland, e-mail: wcz@miiz.waw.pl; \\ agradchenko@hotmail.com; pslipinski@yahoo.com \\ ${ }^{2}$ Hungarian Department of Biology and Ecology, Babeş-Bolyai University, Clinicilor 5-7, 400006 Cluj-Napoca, Romania, \\ e-mail: balintm@gmail.com
}

Key words. Hymenoptera, Formicidae, ants, Formica polyctena, Lasius fuliginosus, Myrmica, competition, conflicts, interspecific hierarchy, territoriality

\begin{abstract}
Competition is a major force organizing ant communities and results in co-occurring species evolving different strategies for foraging and use of space. Territorial species, as top dominants exclude each other, while shaping the local ant communities both qualitatively and quantitatively. In this study we examined how two territorial species, Formica polyctena and Lasius fuliginosus, can coexist in adjacent territories over long periods of time, and whether they affect co-occurring species of ants in different ways. Field observations in the absence and in the presence of baits were carried out around a L. fuliginosus nest complex surrounded by a polydomous $F$. polyctena colony in S Finland in 2007-2009. Both species controlled their territories, but were affected by changes in the abundance of the other species and the distance from L. fuliginosus' main nest. They did not have the same effect on the subordinate species in the absence of baits, but the abundance of Myrmica spp. recorded at baits was negatively affected by both of the territorial species. The preferences of the different species for the artificial food sources differed: L. fuliginosus and F. polyctena preferred tuna to honey and Myrmica spp. honey to tuna. More individuals of the subordinate species were recorded in the territory of $F$. polyctena than of L. fuliginosus, although conflicts with this territorial species were also recorded. During the three years of the study almost no overlaps in the territories of the two territorial species were recorded, and there were mostly minor shifts in the boundaries of the territories. Differences between the two territorial species in their use of space and competitive effects ensured their coexistence at this particular site in Finland.
\end{abstract}

\section{INTRODUCTION}

Ants are particularly competitive, both intra- and interspecifically. Not without reason August Forel (1874) states "the greatest enemies of ants are other ants". The morphological affinity of ants (all species belong to a single family) is accompanied by ecological similarities, which implies considerable niche overlap between species and thus competition. The high density of ants in most terrestrial habitats (Hölldobler \& Wilson, 1990) combined with the generally considerable energy consumptions required to sustain a social mode of life results in ants exerting an immense biotic pressure on their environment and, consequently, on other ants. Close to the boreal zone (e.g. in southern Fennoscandia), competition among ants ought to be particularly strong because the vegetation period is short, average temperatures low and, supposedly, food scarcer than in warmer areas. In addition, the myrmecofauna is much poorer there and ecologically less diversified, than in warmer regions (see e.g. Czechowski et al., 2012). Thus local ant communities in this area are convenient models for research on interspecific competition (e.g. Vepsäläinen \& Pisarski, 1982; Savolainen \& Vepsäläinen, 1988; Pisarski \& Vepsäläinen, 1989; Savolainen et al., 1989; Gallé, 1991; Punttila et al., 1996; Czechowski \& Markó, 2005; Markó \&
Czechowski, 2012). Many aspects of competition between ants has long been studied, ranging from the nature of the interactions (e.g. Möglich \& Alpert, 1979; de Vroey, 1980; Savolainen \& Vepsäläinen, 1989; Savolainen 1991; Czechowski, 1979, 2004) to its role in community structuring (e.g. Vepsäläinen \& Pisarski 1982; Sanders \& Gordon, 2003; Adler et al., 2007). In temperate zones, local assemblages of ant species are hierarchically arranged on the basis of the social organization of their colonies (colony size, dynamic density of foragers, recruitment efficiency, etc.) (Pisarski, 1980). The hierarchy based mainly on three levels of competitive interaction between species: (1) submissive species (those that only defend their nests), (2) encounter species (also defend sources of food) and (3) territorial species (defend all the areas they forage) (Vepsäläinen \& Pisarski, 1982, Savolainen \& Vepsäläinen, 1988, Pisarski \& Vepsäläinen, 1989).

In mature, especially coniferous, Euro-Siberian forests in a range of temperate cold climates, the unquestioned top dominants of ant assemblages are the mound-building wood ants of the Formica rufa-group - e.g. F. polyctena Förster and $F$. rufa Linnaeus. Their role in structuring multi-species ant assemblages and relations with subordinate species is already well known; subordinate ants in

\footnotetext{
* Corresponding author.
} 
the presence of territorial Formica species may shift their activity range in space and time, and may also exploit less rewarding food sources (Savolainen \& Vepsäläinen, 1988, 1989; Savolainen et al., 1989; Vepsäläinen \& Savolainen, 1990; Savolainen, 1991; Punttila et al., 1991, 1996; Czechowski, 2000a; Czechowski \& Vepsäläinen, 2001). Much less is known about Lasius fuliginosus (Latreille) as a possible dominant of ant assemblages. It is a territorial (Dobrzańska, 1966; Zakharov, 1972; Kupyanskaya, 1988; Quinet \& Pasteels, 1996; Czechowski, 1999, 2000a, b; Novgorodova, 2005; Petráková \& Schlaghamerský, 2011) and mostly arboreal-nesting species, present mainly in deciduous and mixed forests (Czechowski et al., 2012). Owing to partly overlapping niches, L. fuliginosus may co-occur with wood ants and seems to actively compete with them for territory. However, there is little data on the competition between these two species (Zakharov, 1972; Romanova, 1975; de Bruyn, 1978; Mabelis, 1984; Czechowski, 1999, 2002).

General features of the foraging strategy and territorial organization in Formica wood ants (see e.g. Dobrzańska, 1958; Rosengren, 1971, 1977a, b; Zakharov, 1972, 1975, 1978, 1991; Mabelis, 1979; Cosens \& Toussaint, 1985; Rosengren \& Fortelius, 1986, 1987; Rosengren \& Sundström, 1987; Sundström, 1993) and Lasius fuliginosus (see e.g. Dobrzańska, 1965, 1966; Zakharov, 1972, 1975, 1978, 1991; Hennaut-Riche et al., 1980; Quinet \& Pasteels, 1991, 1996; Quinet et al., 1997) are similar in many respects. In both of them, trunk-trail foraging is complemented by diffuse hunting; their diet includes both honeydew and animal prey. Both in wood ants and L. fuliginosus, there are more or less well-defined groups of foragers: honeydew collectors and ground-level hunters. In addition, the foraging area is also divided between teams of foragers, with more or less noticeable fidelity of worker groups to specific trails and foraging sites (Rosengren, 1971; Quinet \& Pasteels, 1996). Apart from these general similarities, there is no lack of ambiguous and contradictory information in the literature on whether the foraging strategies of these species differ from each other, as e.g. in forager allocation between permanent (aphids) and ephemeral (invertebrate prey) sources of food. Thus, there could be sufficient differences in the foraging and competitive strategies of these territorial species that they are able to coexist for long periods of time as shown by Petráková \& Schlaghamerský (2011) in their study of neighbouring L. fuliginosus and Liometopum microcephalum (Panzer) nest complexes.

In this study we investigated over a long period of time the differences in space and food utilization by two territorial species of ants, Lasius fuliginosus and Formica polyctena, and their interactions over territory. Based on possible differences in the foraging and space utilization strategies between these two co-dominants in this local ant assemblage, we expect that there could also be noticeable differences in their effect on lower ranked ant species occurring within their territories. These differences could be reflected in changes in the abundance of subordinate species and possible modifications of their for- aging behaviour in the territories of the two dominant species.

\section{MATERIAL AND METHODS}

\section{Study area, species and colonies}

In 2006, we discovered a nest system at the village of Tvärminne $\left(59^{\circ} 50^{\prime} \mathrm{N}, 23^{\circ} 15^{\prime} \mathrm{E}\right)$ on the Hanko Peninsula in Southern Finland, which was suitable for the proposed study: a Lasius fuliginosus nest complex almost surrounded by a Formica polyctena nest complex (Fig. 1). The nest systems were located within a triangular area of just under $5000 \mathrm{~m}^{2}$ enclosed on two sides by converging roads, and the third by a track. The site was overgrown with a mature Scots pine (Pinus sylvestris) forest mixed with some birches and other young trees (rowans, firs). The sandy soil was covered mostly by patches of moss and lichen, and locally with patches of grass and herbaceous vegetation. The nest complex of L. fuliginosus consisted of a big main nest and seven small auxiliary nests. The main nest was, somewhat atypical for the species, being entirely underground with no visible traces of a tree. There were a few nest holes within an area of $1.2 \mathrm{~m}^{2}$. Probably, the colony originally nested in a tree or a tree trunk, which later on was destroyed (at least its aboveground part). The auxiliary nests were dispersed within a $12 \mathrm{~m}$ radius of the main nest and were located mostly in rotten pine trunks. Several L. fuliginosus foraging trails radiated out from the main nest to surrounding trees (up to ca. $15 \mathrm{~m}$ ) (Fig. 1).

The polydomous colony of Formica polyctena originally consisted of four fairly big nests $(0.9-1.2 \mathrm{~m}$ in diameter); then a fifth, smaller nest appeared in 2008. The four big $F$. polyctena nests (FP1, FP2, FP3 and FP4 further on) partly surrounded the Lasius fuliginosus nest complex. They were situated at a distance of 39 to $58 \mathrm{~m}$ from the main nest of L. fuliginosus (Fig. 1). A single nest of one more territorial species, Formica sanguinea Latreille (FS) and two nests of encounter species, Lasius platythorax Seifert (LP) and Camponotus herculeanus (Linnaeus) $(\mathrm{CH})$ completed the ring of possible competitors around the L. fuliginosus colony. The nests of these species were located 42, 20 and $27 \mathrm{~m}$, respectively from the main L. fuliginosus nest (Fig. 1). Submissive species, recorded in both the $L$. fuliginosus and $F$. polyctena territories, were Myrmica ruginodis Nylander, Myrmica schencki Viereck, Leptothorax acervorum (Fabricius), Temnothorax tuberum (Fabricius) and Formica fusca Linnaeus.

\section{Sampling methods}

The studies were carried out in June in 2007-2009. Transects of observation plots were set up to determine, under experimentally undisturbed conditions, the overlaps in the areas searched by the dominant species, distribution and dynamic density of their workers and those of other co-occurring ant species within their territories. In total, seven transects were established in a radial pattern, starting from the main Lasius fuliginosus nest towards the nests of Formica polyctena (FP1, FP2, FP3 and FP4), Formica sanguinea (FS), Lasius platythorax (LP) and Camponotus herculeanus $(\mathrm{CH})$ (Fig. 1). The length of each transect differed and was between 18 and $27 \mathrm{~m}$; each was long enough to cross the border of the L. fuliginosus territory and reach an area definitely beyond the range of $L$. fuliginosus foragers.

Along the transects, observation plots of $0.5 \times 0.5 \mathrm{~m}$ were set up with a $3 \mathrm{~m}$ distance between plot centres. The number of plots set along particular transects ranged from seven to nine depending on the length of the transect. Within plots the number and species of ants were recorded over a period of two minutes. These records were made between $9^{00}-11^{00}$ and $18^{00}-20^{00}$ and 


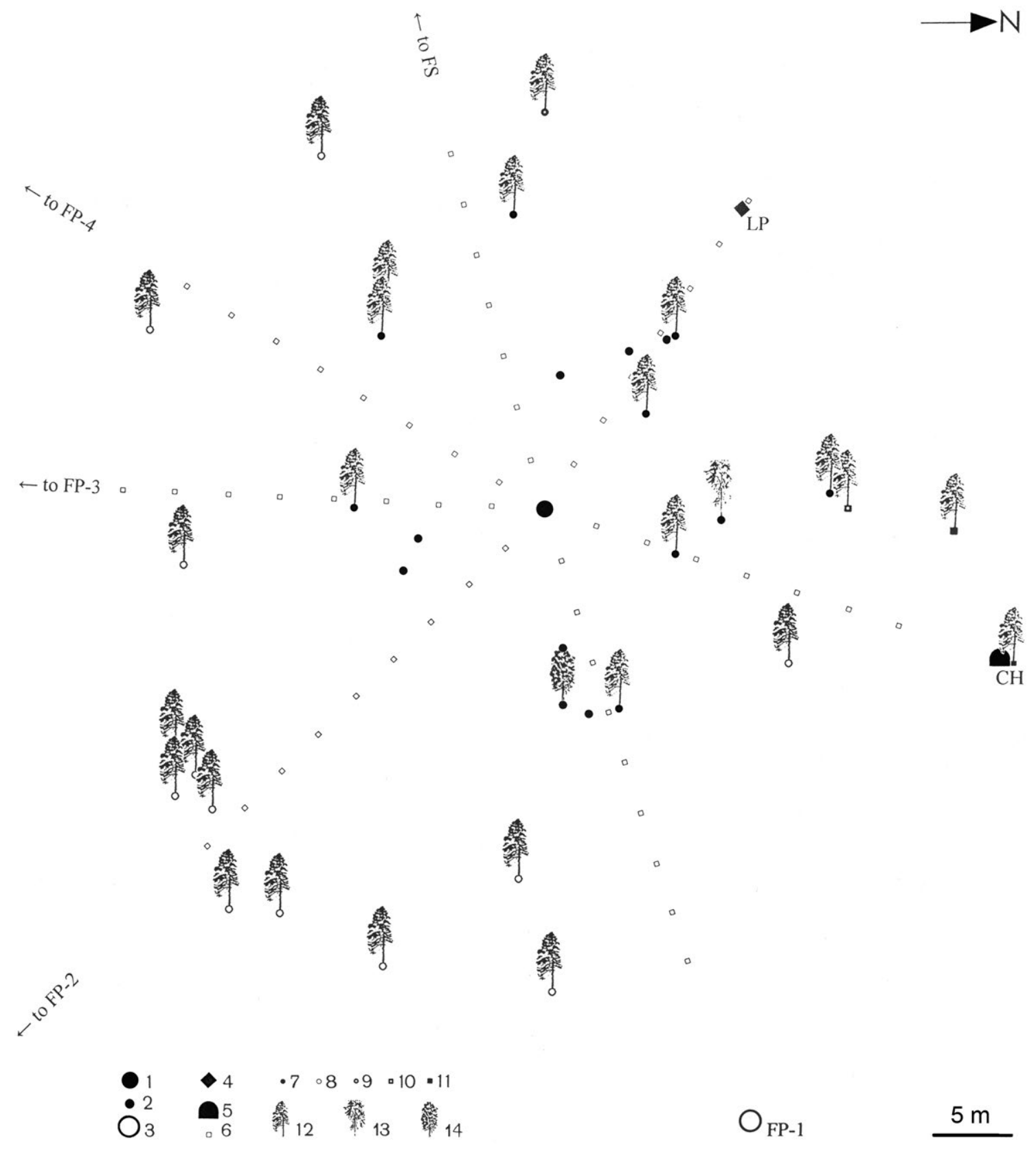

Fig. 1. Map of the study site showing the location of the nests of Lasius fuliginosus and Formica polyctena, transects and the trees surrounding the L. fuliginosus nest complex. 1 - main nest of L. fuliginosus; 2 - auxiliary nest of L. fuliginosus; 3 - nest of $F$. polyctena (FP); 4 - nest of $L$. platythorax (LP); 5 - nest of $C$. herculeanus $(\mathrm{CH}) ; 6$ - observation plot (and bait); 7-11 - trees visited by: 7 - L. fuliginosus; $8-F$. polyctena; $9-F$. sanguinea; $10-$ C. herculeanus; $11-$ Lasius s. str. sp. (as recorded in 2007); 12-14trees: 12 - pine; 13 - fir; 14 - rowan.

there were three series of observations in each period. With the exception of 2009 , the observations each season were performed in the absence of baits (so-called "nudum"), followed by observations in the presence of baits (see below). In the first season (2007), "nudum" observations lasted three days (9-11 June), with one morning and one evening period each day. The following year (2008) there was only one morning and one evening period of observation on 11 June. In 2009, only observations in the presence of baits were recorded.

Baiting is commonly used to study the foraging pattern of ants around their nests and species' foraging strategies. It is also an appropriate method for determining the positions of particular species within an assemblage (e.g. Czechowski, 1979,
1985; Czechowski \& Pisarski, 1988; Gibb \& Parr, 2010; Petráková \& Schlaghamerský, 2011; Markó \& Czechowski, 2012). Of course, appearance of such attractive and easily available food sources, which baits are, alters (mainly increases) the activity of foragers (e.g. Quinet et al., 1997; Czechowski \& Vepsäläinen, 2001; Markó \& Czechowski, 2004; Czechowski \& Markó, 2006; Petráková \& Schlaghamerský, 2011; Markó \& Czechowski, 2012). As the food preferences of ants may change seasonally, two different kinds of bait were provided on each occasion: tuna fish flakes as a source of animal protein food and a water solution of mixed-flower honey as a source of carbohydrate. This setup made it possible to record differences in the food preferences of competing species. The baiting procedure 


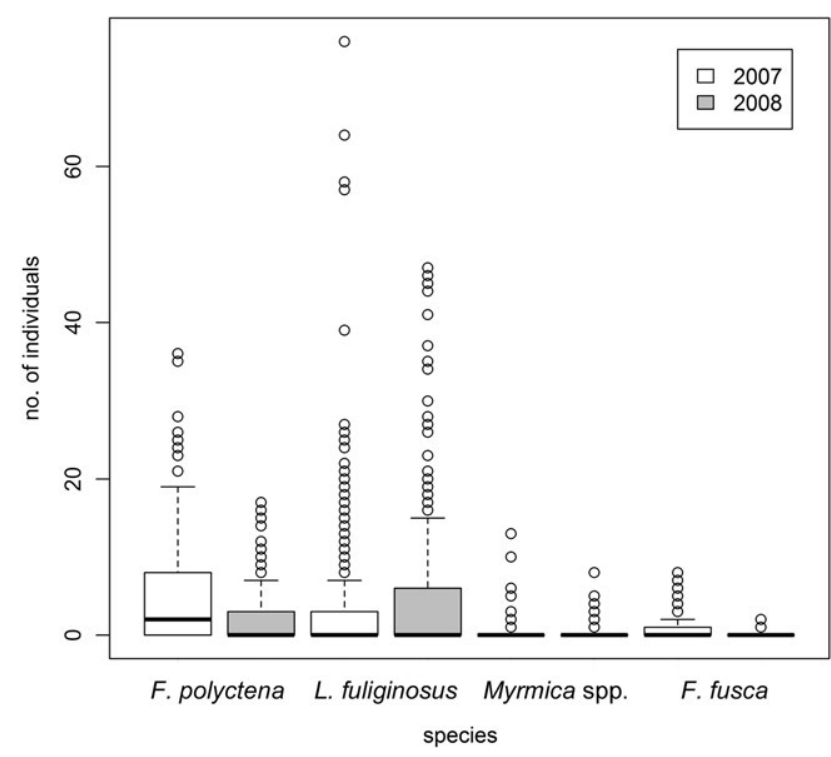

Fig. 2. Abundance of the most frequent species of ants recorded in the observation plots in the absence of baits in 2007 and in 2008 (medians, quartiles, min-max values and outliers).

followed the "nudum" observations. Baits were distributed along the same transects; they were put out in the centre of each plot. The baits were placed on flat plastic caps, $2.5 \mathrm{~cm}$ in diameter, placed side by side and ca. $3 \mathrm{~cm}$ apart, one with tuna and the other with honey. The baits were put out $30 \mathrm{~min}$ before each period of observation (morning, evening) and left there until the end of the period when they were retrieved and the plates cleaned. Each season, as soon after the day of the "nudum" observations as weather allowed the baits were put out. In 2007, they were put out on two days, 14 and 15 June, and on one day in 2008 and in 2009, 12 June and 10 June, respectively. In 2007 and 2008, in the observation periods in the morning and evening there were three series of observations and in 2009 two series. For each pair of baits the number and species of ants present and arriving at the tuna and honey baits were recorded over a period of two minutes.

In order to have a more complete picture, trees around the Lasius fuliginosus nest complex were also inspected for ants collecting honeydew or insect prey from these trees. All trees visited by foragers of $L$. fuliginosus and those in the immediate vicinity visited by foragers of other species of ant were marked and mapped in 2007-2009 (Fig. 1).

\section{Data analysis}

Non-parametric tests were applied as the data sets were nonnormally distributed even after transformation. The abundance of species was compared using Kruskal-Wallis analyses. A generalized linear mixed model (GLMM) approach (Poisson distribution) was used to reveal relationships between the abundance of given species, the distance from the main nest of the Lasius fuliginosus nest complex, and the abundance of rivals separately for "nudum" and bait observations. In the analysis of bait observation results the type of bait (tuna vs. honey) was also incorporated as factor, as well as the interaction of bait type with rival species. Years, observation periods and transects were handled as nested random factors in both cases ("nudum" and bait). The four most abundant species (Formica polyctena, L. fuliginosus, Myrmica spp. and Formica fusca) were included in the analysis of the "nudum" results, while in the case of the bait data $F$. fusca was omitted as very few were recorded (see Results). In order to assess the evenness of the species presence in time,

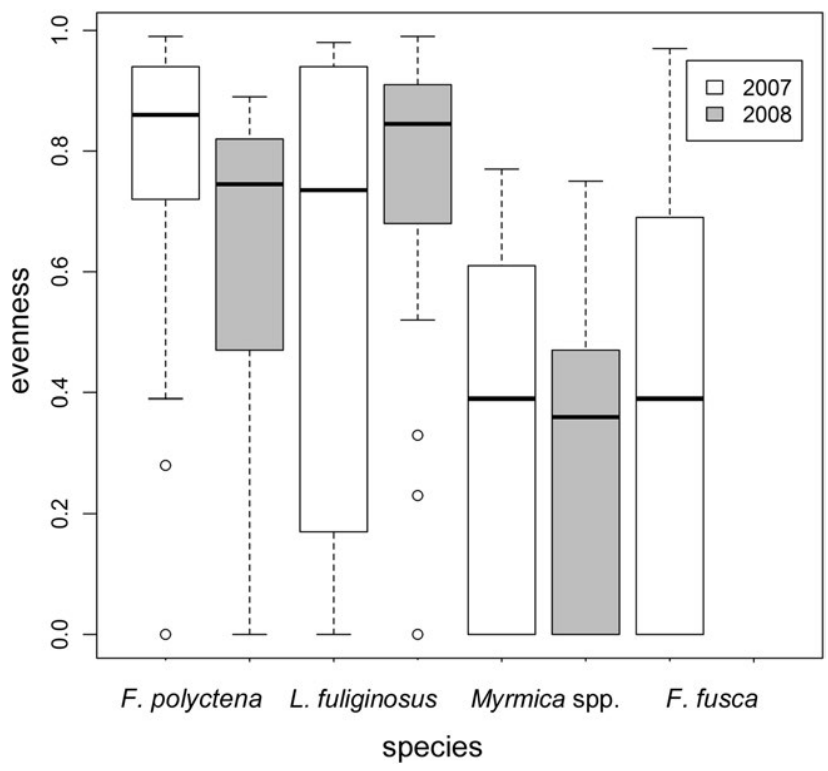

Fig. 3. Evenness in the distribution of the different species of ants in the observation plots along transects recorded in the absence of baits in 2007 and 2008 (based on the evenness of Shannon-Wiener general entropy $\log _{2}$ ) (medians, quartiles, min-max values and outliers).

Shannon-Wiener entropy values $\left(\log _{2}\right)$ and their evenness indices were calculated for each plot separately, and then compared for the four most abundant species using a Kruskal-Wallis analysis. The predictability of the bait exploitation pattern was tested by correlating the mean number of individuals observed in specific plots during the "nudum" observations with the number of individuals recorded at baits during the first observation only for the most abundant species. Data for the two different types of bait were pooled in this case for each plot. Only data for the first day of bait observations was used for the predictability analysis in 2007 , as data recorded on the second day is unlikely to be independent of that recorded on the first day. Food preferences were analyzed using Wilcoxon signed ranktest to compare the number of individuals recorded on honey and tuna baits, respectively, in the same plots during the last period of observation on each day the baits were put out. Only those pairs of data were included for which at least one individual was recorded on one of the baits. Only the three most abundant species were included in this analysis: $F$. polyctena, $L$. fuliginosus and Myrmica spp., as very few $F$. fusca were recorded at baits (see Results). Data for both the days the baits were observed in 2007 were analyzed separately. This analysis could not be performed for Myrmica spp. in the case of the 2008 data as it was scarcely ever recorded at baits (see Results). In the species co-occurrence analysis the number of observations of co-occurrence was taken into consideration. Table-wide sequential Bonferroni-corrections (Rice, 1989) were used in order to reveal the exact significance level when performing multiple analyses of related data sets (e.g. multiple Spearman rank-correlations, Wilcoxon signed rank-tests). All the statistical analyses were carried out using SPSS 9.0 and R 2.12.0 (R Development Core Team, 2010) statistical packages.

Changes in the foraging areas of the species were analyzed using the data on the distribution of species on plots complemented with tree inspection data. Each plot/bait/tree was assigned to one or other of the two dominant species if there was a clear numerical dominance in the numbers recorded. Given the fact that the two rival species did not co-occur almost 


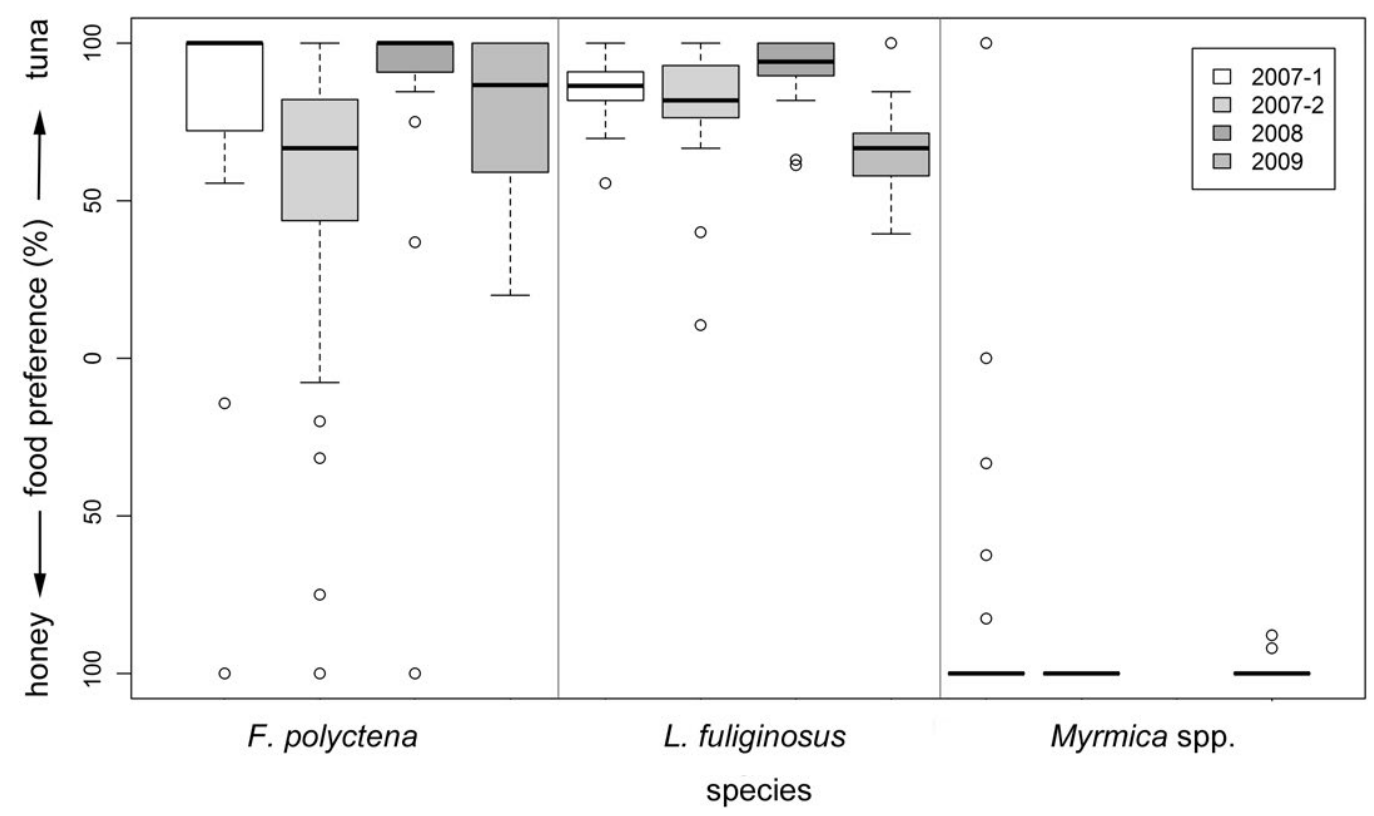

Fig. 4. Percentage of individuals of different species of ants chosing either of the two types of baits in the same observation plots in 2007 ( $1^{\text {st }}$ and $2^{\text {nd }}$ series), 2008 and 2009 (medians, quartiles, min-max values, outliers). There were insufficient data for Myrmica spp. in 2008.

at all (see Results), there was no doubt that the plots/trees were correctly assigned in each case. Based on these data separate maps were produced for the 'nudum' and bait observation data, which were used to assess changes in the areas occupied by the two rival species.

\section{RESULTS}

\section{Distribution of the different species of ants in the absence of baits}

In 2007 in the "nudum" observations, the most abundant ants recorded in the study area were Lasius fuliginosus, Formica polyctena, Myrmica spp. and Formica fusca, with $F$. polyctena as the most numerous species (Fig. 2; Kruskal-Wallis $\chi^{2}=185.62, P<0.0001, N=330$ for all species). Three more species were rarely recorded: five individuals of Temnothorax tuberum, two individuals of Lasius platythorax and one of Camponotus herculeanus. The situation changed drastically in 2008 when $F$. fusca almost totally disappeared (only 26 individuals were recorded vs. 227 in 2007), and L. fuliginosus became the numerically dominant species in the area (Fig. 2; Kruskal Wallis $\chi^{2}=84.63, P<0.001, N=330$ for all species) followed by $F$. polyctena and Myrmica spp. In addition seven workers of $T$. tuberum were recorded.

The number of Formica polyctena individuals increased with distance from the main nest of the Lasius fuliginosus nest complex and decreased with increase in the number of L. fuliginosus foragers (GLMM distance $z$ $=16.7, P<0.0001$, L. fuliginosus $z=-12.06, P<0.0001$, $N=660)$. The reverse was recorded for L. fuliginosus: the number of individuals recorded in plots decreased with distance and with increase in the number of $F$. polyctena foragers (GLMM distance $z=-12.31, P<0.0001, F$. polyctena $z=-20.03, P<0.0001, N=660)$. Of the other species, there was only a slight increase in the abundance of Myrmica spp. with increase in the distance from the main nest of L. fuliginosus, but neither of the other two dominant species seemed to affect its distribution (GLMM distance $z=4.42, P<0.0001, F$. polyctena $z=$ 0.93, $P=$ n.s., L. fuliginosus $z=-1.64, P=$ n.s., $N=660)$. Distribution of $F$. fusca did not show any kind of relationship with distance from the main nest of the L. fuliginosus nest complex or with the abundance of the other two territorial species of ants (GLMM distance $z=0.19, P=$ n.s., $F$. polyctena $z=0.51, P=$ n.s., L. fuliginosus $z=1.29, P$ = n.s., $N=660)$.

There are clear differences in the evenness of the presence of the four most abundant ant species in plots in 2007 (Fig. 3; Kruskal-Wallis $\chi^{2}=34.37, P<0.0001, N_{\mathrm{Fp}}$ $=41, N_{\mathrm{Lf}}=28, N_{\mathrm{Myr}}=27, N_{\mathrm{Ff}}=42$ ). Formica polyctena was the most stable in terms of plots visited, followed by Lasius fuliginosus. A change occurred in 2008, which reflected the numerical dominance of L. fuliginosus in that year (see Fig. 2), it was more stable than $F$. polyctena in terms of plots visited (Fig. 3; Kruskal-Wallis $\chi^{2}=$ $\left.34.43, P<0.0001, N_{\mathrm{Fp}}=36, N_{\mathrm{Lf}}=30, N_{\mathrm{Myr}}=27\right)$.

\section{Foraging of ants when baits were present}

The putting out of baits resulted in change in the distribution patterns of the different ants: the dominance of Lasius fuliginosus became even greater. L. fuliginosus was the most abundant species recorded at baits in all three years: $56 \%, 61.7 \%$ and $52 \%$ of all individuals recorded at baits in 2007, 2008 and 2009, respectively. Formica polyctena was the second most abundant species with $33 \%, 37.8 \%$ and $37 \%$ of the individuals, respectively. Remarkably of the other species, Myrmica spp. made up $9 \%$ in 2007 and $11 \%$ in 2009 of the total number of ants recorded but was almost absent in 2008, when only 27 workers $(0.27 \%)$ were recorded at baits. Other 


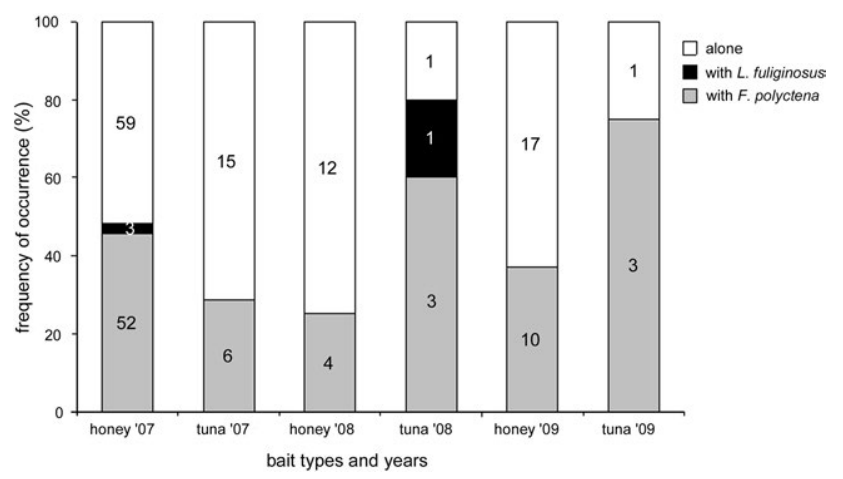

Fig. 5. Frequency of occurrence (\%) and the number of $M y r-$ mica spp. recorded with other species and alone at different types of baits during the three years of the study.

species rarely occurred: Formica fusca 36 individuals $(0.31 \%)$, eight $(0.08 \%)$ and one $(0.05 \%)$ in the three years; Lasius platythorax 204 individuals (1.8\%) recorded only in 2007; Temnothorax tuberum 45 (0.39\%) and three $(0.01 \%)$ individuals in 2007 and 2008, respectively, and a single individual $(<0.01 \%)$ of Camponotus herculeanus in 2008.

It was possible to predict the patterns of exploitation of the three most abundant species based on the "nudum" observations in 2007 and 2008 (Spearman $r, N=55$ in all cases): Formica polyctena $r_{2007}=0.27, P<0.05, r_{2008}=$ $0.9, P<0.001$; Lasius fuliginosus $r_{2007}=0.75, P<0.001$, $r_{2008}=0.89, P<0.001 ;$ Myrmica spp. $r_{2007}=0.58, P<$ $0.001, r_{2008}=0.31, P<0.01$. Only the presence of Formica fusca at baits was not predictable (Spearman $r_{2007}=$ $0.23, P=$ n.s. $)$.

As indicated by the "nudum" observations the number of individuals of Formica polyctena at baits increased with distance from the main nest of the Lasius fuliginosus nest complex, it was negatively associated with the presence of foragers of L. fuliginosus and depended on the type of bait (GLMM distance $z=24.56$, L. fuliginosus $z=$ -5.36 , bait $z=59.45, P<0.0001$ in all cases, $N=1714$ ). Nevertheless the interaction between type of bait and abundance of $L$. fuliginosus had no significant effect on $F$. polyctena (L. fuliginosus $\times$ bait $z=-0.03, P=$ n.s., $N=$ 1714). Similarly, to the "nudum" observations, the number of individuals of L. fuliginosus recorded at baits decreased with distance, it was negatively affected by the presence of foragers of $F$. polyctena and it was dependent on the type of bait (GLMM distance $z=-17.05, F$. polyctena $z=-7.75$, bait $z=83.17, P<0.0001$ in all cases, $N=1714$ ). The interaction between type of bait and the abundance of $F$. polyctena had also no significant effect in this case ( $F$. polyctena $\times$ bait $z=-0.06, P=$ n.s., $N=1714$ ). There was a significant increase in the abundance of Myrmica spp. with distance from the main nest of L. fuliginosus (GLMM distance $z=14.93, P<0.0001$, $N=1714$ ). In addition, the abundance of the two other dominant species also had a significant negative effect on the abundance of Myrmica spp. as did the type of bait $(F$. polyctena $z=-9.22$, L. fuliginosus $z=-5.79$, bait $z=$ $-15.53, P<0.0001$ in all cases, $N=1714$ ). In addition,

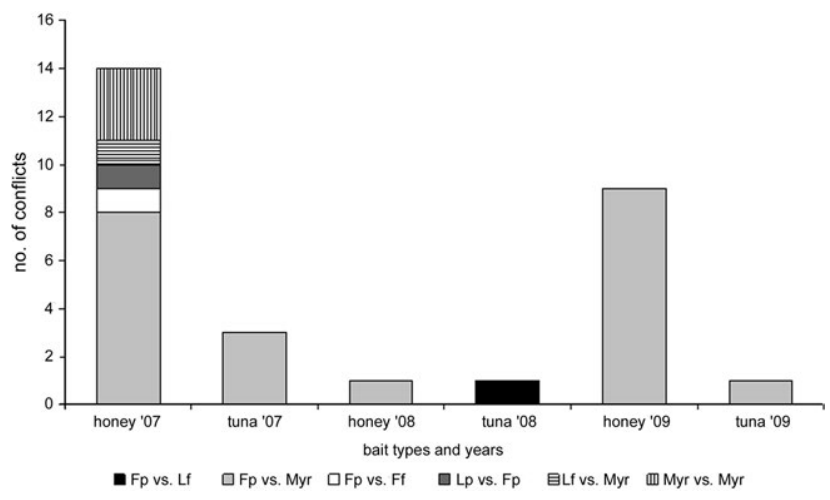

Fig. 6. Number of aggressive interactions between individuals recorded at baits during the course of the study. The first species is the winner ( $\mathrm{Fp}$ - Formica polyctena; $\mathrm{Lf}$ - Lasius fuliginosus; Myr - Myrmica spp.; Ff - F. fusca; Lp - L. platythorax).

the interaction between type of bait and abundance of $L$. fuliginosus also had a marked significant effect on $M y r-$ mica spp. (L. fuliginosus $\times$ bait $z=4.73, P<0.0001, N=$ 1714).

Clear differences were recorded in the food preferences of the three most abundant species based on the results of Wilcoxon signed rank-tests. Lasius fuliginosus preferred tuna to honey (Fig. 4): $V=153, P<0.05$ for $20071^{\text {st }}$ series $(N=17) ; V=276, P<0.001$ for $20072^{\text {nd }} \operatorname{series}(N$ = 23); $V=325, P<0.001$ for $2008(N=25) ; V=91, P<$ 0.05 for $2009(N=13)$. Formica polyctena also preferred tuna although to a less extent than the previous species (Fig. 4): $V=184, P<0.01$ for $20071^{\text {st }}$ series $(N=19) ; V$ $=458, P<0.001$ for $20072^{\text {nd }} \operatorname{series}(N=31) ; V=401, P$ $<0.001$ for $2008(N=28) ; V=630, P<0.001$ for 2009 $(N=35)$. Myrmica spp. preferred honey to tuna in all cases (Fig. 4): $V=296.5, P<0.01$ for $20071^{\text {st }}$ series $(N=$ $25), V=105, P<0.05$ for $20072^{\text {nd }}$ series $(N=14)$ and $V$ $=120, P<0.01$ for $2009(N=15)$.

\section{Competitive effects}

The two dominant territorial species were recorded cooccurring only a few times in plots during the "nudum" observations: 21 and 17 times in 2007 and 2008, respectively. Myrmica spp. seemed to prefer the territory of Formica polyctena to that of Lasius fuliginosus as it cooccurred with $F$. polyctena 14 and 43 times in 2007 and 2008, respectively and only 10 times with L. fuliginous in each of the two years. The introduction of baits resulted in a clearer picture as then L. fuliginosus was almost never recorded along with any other species, except on a few occasions with Myrmica spp. (Fig. 5), but there was one record in 2007 of a $F$. polyctena worker along with six L. fuliginosus on honey bait 3 on FP1 transect, $9 \mathrm{~m}$ from the main nest of the L. fuliginosus nest complex. $F$. polyctena was relatively frequently recorded together with Myrmica spp. (Fig. 5). Myrmica spp., though, occurred more frequently in areas where none of the other species of ants were present (Fig. 5).

Generally, Formica polyctena seemed to be more frequently in conflict with other species (Fig. 6). Although it almost never co-occurred with Lasius fuliginosus, one 


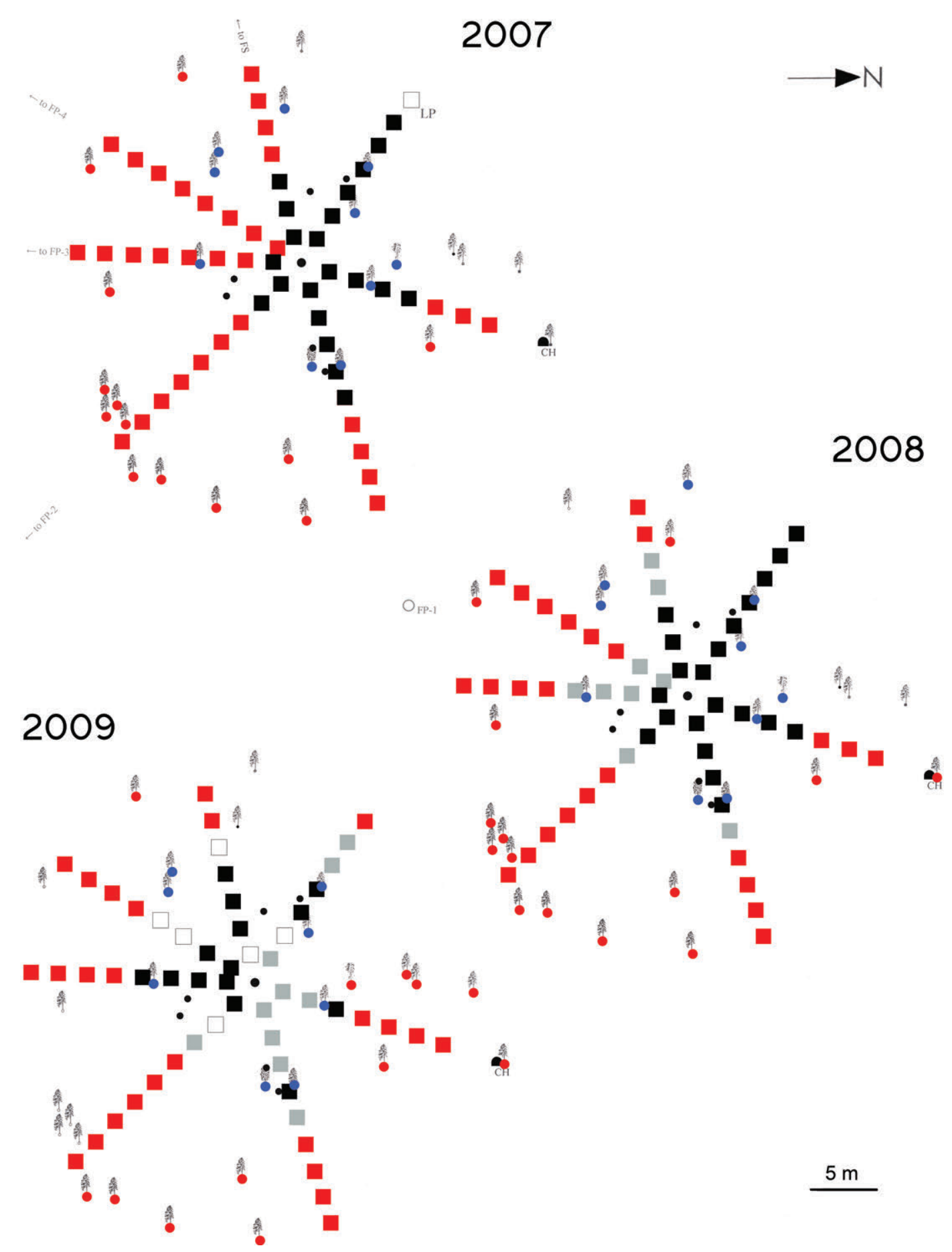

Fig. 7. Distribution of the two territorial species of ants in observation plots along transects in the absence of baits in 2007 and 2008, and in the presence of baits in 2009: black squares - plots occupied by L. fuliginosus; red squares - plots occupied by $F$. polyctena; grey squares - new plots for L. fuliginosus in 2008 in relation to data for 2007 and new plots for F. polyctena in 2009 in relation to data for 2008; empty squares - unfrequented plots; black dots - L. fuliginosus nests (big dot - main nest, small dots - auxiliary nests); blue dots - trees visited by L. fuliginosus; red dots - trees visited by F. polyctena (for more details see Fig. 1).

conflict was recorded between them, when L. fuliginosus was forced to give up a tuna chunk at bait 5 on transect LP in 2008. The majority of the aggressive interactions occurred between F. polyctena and Myrmica spp. since they were the only species of ants that co-occurred frequently, mostly at honey and not at tuna baits (Fig. 6). All such conflicts resulted at least in the temporary displacement of Myrmica individuals from baits. The same out- come was recorded for the single conflict recorded between Myrmica spp. and L. fuliginosus (Fig. 6). F. polyctena lost only one conflict in which it was driven away by a L. platythorax worker from bait 7 on transect LP, which was close to the L. platythorax nest in 2007 . Additionally, in 2007, an attack by L. fuliginosus on a nest of Temnothorax tuberum, which was located ca. 20 $\mathrm{m}$ from the main nest of L. fuliginosus between transects 
FS and LP, was observed. The attackers removed $T$. tuberum larvae and pupae and took them back to their nest.

\section{Changes in the partitioning of space by the two territorial species}

In the absence of baits Lasius fuliginosus and Formica polyctena divided the area studied and there was no buffer zone, a so called no-ant-land, between these species in 2007 and 2008 (Fig. 7). Both species were recorded along most transects (Fig. 7). F. polyctena dominated along transect FP4 in 2007, whereas L. fuliginosus was totally absent, although it gained ground in 2008. In its turn, L. fuliginosus dominated and $F$. polyctena was absent along transect LP in both years (Fig. 7).

The setting of baits did not result in any big differences in the partitioning of space by the two species in 2007 and 2008. Both species gained one additional plot along several transects: (a) in 2007 Lasius fuliginosus at FP2, FP3 and FP4, and Formica polyctena at $\mathrm{CH}$, and (b) in 2008 F. polyctena at FP1, FP2 and FS. A border conflict between the two territorial species was also observed in 2008. It took place close to a tree exploited by L. fuliginosus located along transect FP3 (Fig. 7). The conflict occurred on the ground about $1 \mathrm{~m}$ south-east of the tree trunk. The conflict, which was not very fierce, continued during the whole period of observation. Next year the tree in question was still occupied by L. fuliginosus.

In 2009, both species seemed to lose ground although to different extent (Fig. 7): Lasius fuliginosus gave up plots along transects FP1, FP2, FS, LP. In its turn, Formica polyctena ceased to be recorded at some plots FP4 although it gained ground along transects FP1, LP and $\mathrm{CH}$. In contrast to previous years, ants were not recorded at a number of baits, most of which were at the borderline between the territories of the two species. Some were even inside the territory of L. fuliginosus, which appeared to be more fragmented than in previous years.

\section{DISCUSSION AND CONCLUSIONS}

Territorial ants, as top dominants, efficiently monopolize rich food sources present in their foraging area, while also shaping the local ant communities directly or indirectly. By definition two territorial species cannot occupy the same territory, and even the occupation of adjacent territories is likely to result in conflicts, which could ultimately lead to the territory of one of the species being occupied by the other species, especially in periods of food shortage (see Mabelis, 1979; Pisarski, 1982). An overlap in the territories of two species is only possible if one of the species is adapted specifically for coexistence with other species or they differ in their foraging activity (see e.g. Czechowski \& Markó, 2005; Petráková \& Schlaghamerský, 2011). The side by side occurrence of allospecific territorial species, such as the wood ants, Formica polyctena and F. rufa, and Lasius fuliginosus, is quite rare in the temperate zone (see e.g. Czechowski, 1999; Petráková \& Schlaghamerský, 2011), thus our par- ticular case offered the possibility of studying the rules for coexistence in the field.

Although both Formica polyctena and Lasius fuliginosus are territorial species, they differ from each other with regards to their utilization of space. As wood ants allocate considerable numbers of foragers both to tend aphids and hunt for insect prey on the forest floor (Dobrzańska, 1958, 1965; Rosengren, 1971; Sundström, 1993; Novgorodova \& Reznikova, 1996; Reznikova \& Novgorodova, 1998a, b; Novgorodova, 2005) the whole of their territory is patrolled by foragers. However, in the case of L. fuliginosus most of the foragers are involved with tending aphids on certain trees and the area around them and are, therefore, recorded mainly on trails between the nest and the trees on which the aphids occur (Dobrzańska, 1965, 1966; Quinet \& Pasteeels, 1991; Quinet et al., 1997; Petráková \& Schlaghamerský, 2011). This spatial bias is compensated for by the highly efficient system for mobilizing workers from the nearest foraging trail when prey is found in the vicinity on the forest floor (Dobrzańska, 1965, 1966; Quinet \& Pasteeels, 1991; Quinet et al., 1997), and by the relative plasticity (lack of specialization) of the honeydew collectors (Zakharov, 1972; Quinet et al., 1997; Novgorodova, 2005).

As the key to the dominance of a specific area is the continual presence there of a species, then in a competitive situation Formica polyctena would seem to be at an advantage as it usually occupies an area more efficiently, than its rival (see e.g. Petráková \& Schlaghamerský, 2011). Consequently, it is most likely to be the first to exploit an ephemeral food source, at least compared to Lasius fuliginosus. However, our data indicates that $L$. fuliginosus was also present in the area in "nudum" treatment in comparably high numbers, moreover, as already demonstrated by other studies (Dobrzańska, 1965, 1966; Quinet \& Pasteeels, 1991; Quinet et al., 1997), it can quick and massively mobilize foragers to exploit newly discovered food sources. In this respect, there is a clear difference in the foraging strategy of L. fuliginosus in the northern population studied and in the temperate warm zone, where it controls significantly less of the area around its aphid trees and allocates relatively few workers to searching the surface of the soil surface for insect prey (see Dobrzańska, 1965, 1966; Quinet \& Pasteeels, 1991; Quinet et al., 1997; Petráková \& Schlaghamerský, 2011). This difference may be attributed to the fact that at the northern border of its range the available aphid colonies do not provide L. fuliginosus with enough food to sustain a nest complex as big as the one we studied, and the species allocates more foragers to searching the surface of the soil. The less random nature of the foraging on ground by L. fuliginosus is also supported by the predictable character of bait exploitation, which is similar to that of $F$. polyctena.

The increase in the abundance of Lasius fuliginosus from 2007 to 2008, recorded by the results of both the "nudum" and bait observations, was greater than that recorded for Formica polyctena, which could reflect 
changes in the quality and/or quantity of food sources on trees (honeydew and insects). These changes could have been triggered by climatic factors. A reduction in the quantity of food available on trees could result in the ants foraging more on the ground, and, ultimately, in L. fuliginosus becoming more aggressively competitive. This would also explain the observed reduction in the numbers of submissive species recorded in the territory of $L$. fuliginosus. Based solely on the numbers recorded at baits an opposite trend in abundance occurred in 2009: there was a decrease in the abundance and size of the territory of $L$. fuliginosus (see Fig. 7).

There are clear differences between the two territorial species in terms of their food preferences. Generally, a discovery bias could influence the resulting pattern. We consider, though that the duration of baiting observations was long enough to ensure the emergence of an accurate picture of the true preferences as ants that locate a preferred food quickly recruit other ants to the source. The clear-cut differences observed in food preferences of the three most abundant species of ants also support the accuracy of the observed pattern (see Fig. 4). While Formica polyctena exploited both sources (although preferring animal protein), the Lasius fuliginosus foragers were almost exclusively recorded on tuna baits. Quinet et al. (1997) also observed that L. fuliginosus is not attracted to sucrose baits later in the season, while meat baits elicit strong recruitment, even of foragers previously recorded at aphid sites or sucrose baits (ca. 9\% of foragers) (Quinet et al., 1997). On the other hand, there is indirect evidence to suggest that foragers of Formica cinerea Mayr, living in the same area, are mostly recruited from the nest (Markó \& Czechowski, 2012). The marked preference of L. fuliginous for tuna over honey indicates that for this species there was a shortage of food rich in animal protein. While $F$. polyctena can easily supplement its need for animal protein by foraging in other areas, the area available for foraging to L. fuliginosus is either limited by $F$. polyctena or the road (see Material and Methods). These factors could clearly limit the growth of the $L$. fuliginosus nest complex by imposing a ceiling, which could only be breached by driving away $F$. polyctena.

The existence of a delicate balance between the two species is supported by their negative numerical responses to the increase in abundance of the other species, and by their mutual avoidance: they were very rarely recorded together at the same place or at the same bait. There was no clear enemy free zone between the two territories and the border was generally weakly defined except in specific parts of the territories (see Fig. 7). The two dominant species had clearly different effects on cooccurring ant species. Many conflicts were recorded between Myrmica spp. and Formica polyctena, but Myrmica spp. continued to forage in the territory of this species. Generally, co-occurring species tended to avoid Lasius fuliginosus or even its territory, although clear responses were only recorded for Myrmica spp. In this respect differences in the chemical weapons of the dominant territorial species could account for these diffe- rences: $F$. polyctena uses formic acid, while the main weapon of L. fuliginosus is dendrolasin (Pavan, 1959), which both deters and is an irritant. Effectiveness of dendrolasin is well demonstrated by the reports of the results of conflicts between L. fuliginosus and territorial Formica species (Czechowski, 1999, 2000a), and L. fuliginosus and Liometopum microcephalum (Petráková \& Schlaghamerský, 2011). The aforementioned potential shortage of animal protein for Lasius fuliginosus could result in stronger competitive or even predatory pressures on cooccurring ants. It is known, that L. fuliginosus generally has a strong effect on the numbers of subordinate species of ant, most noticeably in reducing their occurrence both qualitatively (reduced species richness) and quantitatively (decreased nest density) (Czechowski, 2002; Rzeszowski, 2011). In our case this is clearly documented by the attack on a Temnothorax tuberum colony.

In their study on the interactions of Liometopum microcephalum with Lasius fuliginosus and Formica rufa, Petráková \& Schlaghamerský (2011) record substantial changes in the territory size of $L$. fuliginosus between years. These changes occurred in spring and the territory remained mostly unaltered during the active season. In our case only slight, almost insignificant changes occurred in territory size with the exception of 2009. The location of trees housing aphid colonies was the dominant feature of the territory of L. fuliginosus, which are like islands within the continuous territory of $F$. polyctena, and are probably connected by underground tunnels to the core area of the nest complex, as indicated by Petráková \& Schlaghamerský (2011). The tree occupancy data for 2009 indicate that $F$. polyctena exploited aphid food sources in one part of the territory previously unoccupied or occupied in parts by L. fuliginosus. Some previous data show that L. fuliginosus may, although not without losses, systematically also increase its territory at the expense of wood ants (Czechowski, 1999). The reverse also occurs: a strong $F$. polyctena colony is able to destroy a L. fuliginosus colony within one season (most probably in spring), taking over its whole territory including the tree with its nest (W. Czechowski, unpubl.).

Ideally, an ant colony should maximize the acquisition of food by matching the distribution of foragers to that of the availability of food around nests (de Biseau \& Pasteels, 2000; Detrain et al., 2000; Gordon et al., 2008; Beverly et al., 2009; Markó \& Czechowski, 2012), or sometimes even by arranging the structure of the colony to more closely fit the pattern in the distribution of food, as sometimes occurs in multi-nest systems (Czechowski, 1975; Cerdá et al., 2002; Petráková \& Schlaghamerský, 2011). In our case Lasius fuliginosus developed a large nest complex, which was or became surrounded by a rival Formica polyctena nest complex. It is clear that $F$. polyctena limited the further spread in space of $L$. fuliginosus, which might result in it increasing its competitive or even predatory pressure on $F$. polyctena. Although there were very few border conflicts, even when food was provided that was worth fighting for, it is fair to assume that the delicate balance between the two neighbours only 
persisted because these species were able to find sufficient food to sustain their development either in neighbouring territories in the case of $F$. polyctena, or in their existing territory in the case of L. fuliginosus. While the first case seems to be a plausible scenario, in L. fuliginosus a regression is expected in the squeeze of the rival.

ACKNOWLEDGEMENTS. We are indebted to T. Radchenko for valuable help with fieldwork in 2007. Comments of an unknown reviewer helped to improve considerably the original version of the manuscript. B. Markó's stay in Finland was supported by 31/1342 CNCSIS (2006-2008), ID-552 IDEI PNII (2007-2009) and Communitas Fund (Cluj-Napoca, Romania) grants. During the preparation of the manuscript B. Markó received considerable help from PL-TAF-2010 and 3066 Synthesys EU FP 6 grants, and the scientific cooperation program between the Polish Academy of Sciences and the Romanian Academy. W. Czechowski's and A. Radchenko's stays in Finland took place within the framework of a scientific cooperation program between the Polish Academy of Sciences and the Academy of Finland. The authors are grateful for the help with fieldwork provided by the Tvärminne Zoological Station of the University of Helsinki.

\section{REFERENCES}

Adler F.R., LeBrun E.G. \& FeEner D.H. JR 2007: Maintaining diversity in an ant community: modeling, extending and testing the dominance-discovery trade-off. - Am. Nat. 169: 323-333.

Beverly B.D., McLendon H., Nacu S., Holmes S. \& Gordon D.M. 2009: How site fidelity leads to individual differences in the foraging activity of harvester ants. - Behav. Ecol. 20: 633-638.

Biseau J.-C. DE \& Pasteels J.M. 2000: Response thresholds to recruitment signals and the regulation of foraging intensity in the ant Myrmica sabuleti (Hymenoptera, Formicidae). Behav. Proc. 48: 137-148.

BRUYN DE G.J. 1978: Food territories in Formica polyctena (Först.). - Neth. J. Zool. 28: 55-61.

Cerdá X., Dahbi A. \& Retana J. 2002: Spatial patterns, temporal variability, and the role of multi-nest colonies in a monogynous Spanish desert ant. - Ecol. Entomol. 27: 7-15.

Cosens D. \& Toussaint N. 1985: An experimental study of the foraging strategy of the wood ant Formica aquilonia. Anim. Behav. 33: 541-552.

Czechowski W. 1975: Bionomics of Formica (Coptoformica) pressilabris Nyl. (Hymenoptera, Formicidae). - Ann. Zool. 33: $103-125$.

Czechowski W. 1979: Competition between Lasius niger (L.) and Myrmica rugulosa Nyl. (Hymenoptera, Formicidae). Ann. Zool. 34: 437-451.

Czechowski W. 1985: Competition between Myrmica laevinodis Nyl. and Lasius niger (L.) (Hymenoptera, Formicoidea). Ann. Zool. 39: 153-173.

CzechowsKi W. 1999: Lasius fuliginosus (Latr.) on a sandy dune - its living conditions and interference during raids of Formica sanguinea Latr. (Hymenoptera, Formicidae). - Ann. Zool. 49: 117-123.

CZEChOWSKI W. 2000a: Interference of territorial ant species in the course of raids of Formica sanguinea Latr. (Hymenoptera, Formicidae). - Ann. Zool. 50: 35-38.

Czechowski W. 2000b: The Jet Ant, Lasius fuliginosus, on guard of status quo in a multi-species ant assemblage. Notatki Entomol. 1(1): 11-14 [in Polish].
Czechowski W. 2002: Lasius fuliginosus (Latr.) (Hymenoptera, Formicidae) as a facultative myrmecophagan. - Przegl. Zool. 46: 243-246 [in Polish].

CZECHOWski W. 2004: Submissive posture of Myrmica rugulosa Nyl. in its interspecific relations (Hymenoptera, Formicidae). - Przegl. Zool. 48: 19-28 [in Polish, English abstr.].

Czechowski W. \& Markó B. 2005: Competition between Formica cinerea Mayr (Hymenoptera: Formicidae) and cooccurring ant species, with special reference to Formica rufa L.: direct and indirect interferences. - Pol. J. Ecol. 53: 467-487.

CZeChowsKi W. \& MARKó B. 2006: Uncomfortable protection: Formica polyctena Först. shelters Formica fusca L. from Formica sanguinea Latr. (Hymenoptera: Formicidae). - Ann. Zool. 56: 539-548.

Czechowski W. \& Pisarski B. 1988: Inter- and intraspecific competitive relations in Camponotus ligniperdus (Latr.) (Hymenoptera, Formicidae). - Ann. Zool. 41: 355-381.

CZECHOWSKI W. \& VePSÄLÄINEN K. 2001: Formica rufa protects indirectly $F$. fusca against raids of $F$. sanguinea. - Ann. Zool. 51: 267-273.

Czechowski W., Radchenko A., CzechowsKa W. \& VepsäläInen K. 2012: The Ants of Poland with Reference to the Myrmecofauna of Europe. Fauna Poloniae (New Series) Vol. 4. Museum and Institute of Zoology PAS, Warsaw, 496 pp.

Detrain C., Tasse O., Versaen M. \& Pasteels J.M. 2000: A field assessment of optimal foraging in ants: trail patterns and seed retrieval by the European harvester ant Messor barbarus. - Insectes Soc. 47: 56-62.

DoBRZAŃSKA J. 1958: Partition of foraging grounds and modes of conveyings information among ants. - Acta Biol. Exp. 18: $55-67$.

DoBRZAŃSKA J. 1965: On ethology of Lasius fuliginosus (Formicidae). Proceedings of the VIII Convention of the Polish Zoological Society. Olsztyn, pp. 107-109 [in Polish].

DoBRZAŃSKA J. 1966: The control of the territory by Lasius fuliginosus Latr. - Acta Biol. Exp. 26: 193-213.

Forel A. 1874: Les Fourmis de la Suisse. Société Helvétique des Sciences Naturelles, Zurich, iv $+452 \mathrm{pp}$

GALLÉ L. 1991: Structure and succession of ant assemblages in a north European sand dune area. - Holarct. Ecol. 14: 31-37.

GiBB H. \& PARR C.L. 2010: How does habitat complexity affect ant foraging success? A test using functional measures on three continents. - Oecologia 164: 1061-1073.

Gordon D.M., Holmes S. \& NACU S. 2008: The short-term regulation of foraging in harvester ants. - Behav. Ecol. 19: 217-222.

Hennaut-Riche B., Josens G. \& Pasteels J.M. 1980: L'approvisionnement du nid chez Lasius fuliginosus: pistes, cycles d'activité et spécialisation territorial des ouvrières. In Cherix D. (ed.): Ecologie des Insectes Sociaux. C. R. UIEIS Sect. fr., 7-8 Sept. 1979. UIEIS, Nyon, Lausanne, pp. 71-78.

Hölldobler B. \& Wilson E.O. 1990: The Ants. Harvard University Press, Cambridge, MA, 732 pp.

KUPYANSKAYA A.N. 1988: Far-Eastern representative of the genus Liometopum (Hymenoptera, Formicidae). - Vestnik Zool. 1988(1): 29-34 [in Russian].

MABELIS A.A. 1979: Wood ant wars: the relationship between aggression and predation in the red wood ant (Formica polyctena Först.). — Neth. J. Zool. 29: 451-620.

MABELIS A.A. 1984: Interference between wood ants and other ant species. - Neth. J. Zool. 34: 1-20.

Markó B. \& CZechowsKi W. 2004: Lasius psammophilus Seifert and Formica cinerea Mayr (Hymenoptera: Formicidae) on sand dunes: conflict and coexistence. - Ann. Zool. 54: 365-378. 
Markó B. \& Czechowski W. 2012: Space use, foraging success and competitive relationships in Formica cinerea (Hymenoptera, Formicidae) on sand dunes in southern Finland. Ethol. Ecol. Evol. 24: 149-164.

Möglich M.H.J. \& Alpert G.D. 1979: Stone dropping by Conomyrma bicolor (Hymenoptera: Formicidae): a new technique of interference competition. - Behav. Ecol. Sociobiol. 6: $105-113$.

Novgorodova T.A. 2005: Ant-aphid interactions in multispecies ant communities: some ecological and ethological aspects. Eur. J. Entomol. 102: 495-501.

Novgorodova T.A. \& ReZNIKOVA ZH.I. 1996: Ecological aspects of interactions between ants and aphids in the forest park zone of the Novosibirsk Scientific Center. - Siber. J. Ecol. 3/4 239-245.

Pavan M. 1959: La dendrolasina. - Not. For. Mont. 64/65 1737-1740.

Petráková L. \& Schlaghamerský J. 2011: Interactions between Liometopum microcephalum (Formicidae) and other dominant ant species of sympatric occurrence. - Comm. Ecol. 12(1): 9-17.

PISARSKI B. 1980: Evolution of the competitive behaviour in social insects. - Insectes Soc. 27: 284-287.

PisARSKi B. (ed.). 1982: Structure et organisation des societés de fourmis de l'espèce Formica (Coptoformica) exsecta Nyl. (Hymenoptera, Formicidae). - Memorab. Zool. 38: 1-281.

PISARSKI B. \& VEPSÄLÄINEN K. 1989: Competitive hierarchy in ant communities (Hymenoptera, Formicidae). - Ann. Zool. 42: $321-329$.

Punttila P., Haila Y., Pajunen T. \& Tukia H. 1991: Colonisation of clearcut forests by ants in the southern Finnish taiga: a quantitative survey. - Oikos 61: 250-262.

Punttila P., Haila Y. \& Tukia H. 1996: Ant communities in taiga clearcuts: habitat effects and species interactions. Ecography 19: 16-28.

Quinet Y. \& Pasteels J.M. 1991: Spatiotemporal evolution of the trail network in Lasius fuliginosus (Hymenoptera: Formicidae). - Belg. J. Zool. 121: 55-72.

Quinet Y. \& Pasteels J.M. 1996: Spatial specialization of the foragers and foraging strategy in Lasius fuliginosus (Latreille) (Hymenoptera, Formicidae). - Insectes Soc. 43: 333-346.

Quinet Y., DE Biseau J.-C.D. \& Pasteels J.M. 1997: Food recruitment as a component of the trunk-trail foraging behaviour of Lasius fuliginosus (Hymenoptera: Formicidae). Behav. Process. 40: 75-83.

R Development Core Team 2010: R: A Language and Environment for Statistical Computing. R Foundation for Statistical Computing, Vienna, URL http://www.R-project.org/.

Rice W.R. 1989: Analyzing tables of statistical tests. - Evolution 43: 223-225.

ReZnikova Zh.I. \& Novgorodova T.A. 1998a: The importance of individual and social experience for interaction between ants and symbiotic aphids. - Dokl. Biol. Sci. 359: 173-175.

Reznikova Zh.I. \& Novgorodova T.A. 1998b: Division of labour and exchange of information within ant settlements. Usp. Sovrem. Biol. 118: 345-357 [in Russian, English abstr.].

Romanova Yu.S. 1975: Ecology of the black shiny ant Lasius fuliginosus. In: Proceedings of the VIth All-Union Myrmecological Symposium "Ants and Forest Protection". Moscow, pp. 167-170 [in Russian].
ROSENGREN R. 1971: Route fidelity, visual memory and recruitment behaviour in foraging wood ants of the genus Formica (Hymenoptera: Formicidae). — Acta Zool. Fenn. 133: 1-106.

ROSENGREN R. 1977a: Foraging strategy of wood ants (Formica rufa group). I. Age polyethism and topographic traditions. Acta Zool. Fenn. 149: 1-30.

RosengREN R. 1977b: Foraging strategy of wood ants (Formica rufa group). II. Nocturnal orientation and diel periodicity. Acta Zool. Fenn. 150: 1-29.

RosengRen R. \& ForTelius W. 1986: Ortstreue in foraging ants of the Formica rufa group - hierarchy of orienting cues and long-term memory. - Insectes Soc. 33: 306-337.

Rosengren R. \& Fortelius W. 1987: Trail communication and directional recruitment to food in red wood ants (Formica). - Ann. Zool. Fenn. 24: 137-146.

RosENGREN R. \& SUNDSTRÖM L. 1987: The foraging system of a red wood ant colony (Formica s. str.) - collecting and defending food through an extended phenotype. In Pasteels J.M. \& Deneudourg J.L. (eds): From Individual to Collective Behaviour in Social Insects. Birkhäuser, Basel, pp. 117-139.

RzESZOWsKi K. 2011: Territorialism of Lasius fuliginosus (Latr.) (Hymenoptera: Formicidae): Effects on the Occurrence and Nest Densities of Subordinate Species. MSc. thesis, Warsaw University of Life Sciences - SGGW, Warszawa, 55 pp. [in Polish, English abstr.].

SANDERS N.J. \& GoRdon D.M. 2003: Resource-dependent interactions and the organization of desert ant communities. Ecology 84: 1024-1031.

SAVOLAINEN R. 1991: Interference by wood ant influences size selection and retrieval rate of prey by Formica fusca. Behav. Ecol. Sociobiol. 28: 1-7.

SAVOLAINEN R. \& VePSÄLÄINEN K. 1988: A competition hierarchy among boreal ants: impact on resource partitioning and community structure. - Oikos 51: 135-155.

SAVOlAINEN R. \& VEPSÄLÄINEN K. 1989: Niche differentiation of ant species within territories of the wood ant Formica polyctena. - Oikos 56: 3-16.

Savolainen R., Vepsäläinen K. \& Wuorenrinne H. 1989: Ant assemblages in the taiga biome: testing the role of territorial wood ants. - Oecologia 81: 481-486.

SundSTRÖM L. 1993: Foraging responses of Formica truncorum (Hymenoptera; Formicidae); exploiting stable vs spatially and temporally variable resources. - Insectes Soc. 40: 147-161.

VepsäläInen K. \& PisARsKi B. 1982: Assembly of island ant communities. - Ann. Zool. Fenn. 19: 327-335.

VEPSÄLÄINEN K. \& SAVOLAINEN R. 1990: The effect of interference by Formicine ants on the foraging of Myrmica. $-J$. Anim. Ecol. 59: 643-654.

VROEY DE C. 1980: Relations interspécifiques chez les fourmis. In Cherix D. (ed.): Ecologie des Insectes Sociaux. C. R. UIEIS Sect. fr., 7-8 Sept. 1979. UIEIS, Nyon, Lausanne, pp. 107-113.

ZAKHAROv A.A. 1972: Intraspecific Relations in Ants. Nauka, Moskva, 216 pp. [in Russian].

ZAKHAROv A.A. 1975: Evolution of the social mode of life in ants. - Zool. Zh. 54: 861-872 [in Russian, English abstr.].

Zakharov A.A. 1978: Ant, Colony, Polycalic Colony. Nauka, Moskva, 144 pp. [in Russian].

ZaKharov A.A. 1991: The Organization of Ants' Communities. Nauka, Moskva, 300 pp. [in Russian, English abstr.].

Received July 4, 2012; revised and accepted October 26, 2012 